\title{
Perceptions of Teachers and School Nurses on Child and Ado- lescent Oral Health
}

\author{
Carl A. Maida 1, Mavin Marcus ${ }^{1}$, Di Xiong 1, 2 , Paula Ortega-Verdugo ${ }^{3}$, Elizabeth Agredano ${ }^{1}$, Yilan Huang 1, ${ }^{2}$, \\ Linyu Zhou 1, 2, Steve Y. Lee ${ }^{3}$, Jie Shen 1, Ron D. Hays 4, 5, 6, James J. Crall 1, and Honghu Liu 1, 2, 4,*
}

1 Division of Oral and Systemic Health Sciences, School of Dentistry, University of California Los Angeles, CA 90095, USA; cmaida@ucla.edu (C.A.M.); mmarcus@dentistry.ucla.edu (M.M.); eagredano@outlook.com (E.A.); shenjie@ucla.edu (J.S.); jcrall@dentistry.ucla.edu (J.J.C.); hhliu@dentistry.ucla.edu (H.L.)

2 Department of Biostatistics, Fielding School of Public Health, University of California Los Angeles, CA 90095, USA; dixiong@ucla.edu (D.X.); yilanh19@ucla.edu (Y.H.); linyuzhou@ucla.edu (L.Z.)

3 Division of Preventative and Restorative Sciences, School of Dentistry, University of California Los Angeles, CA 90095, USA; portegaverd@ucla.edu (P.O.); slee@dentistry.ucla.edu (S.Y.L.)

4 Division of General Internal Medicine and Health Services Research, David Geffen School of Medicine, University of California Los Angeles, CA 90095, USA; drhays@ucla.edu (R.D.H.)

5 Department of Health Policy and Management, Fielding School of Public Health, University of California Los Angeles, CA 90095, USA;

6 RAND Corporation, Santa Monica, CA 90407, USA;

* Correspondence: hhliu@dentistry.ucla.edu

\begin{abstract}
This study reports results of focus groups with school nurses and teachers from elementary, middle, and high schools to explore their perceptions of child and adolescent oral health. Participants included 14 school nurses and 15 teachers (83\% Female; 31\% Hispanic, 21\% White, 21\% Asian, 14\% African American, and 13\% Others). Respondents were recruited from Los Angeles County schools and scheduled by school level for six one-hour focus groups, using Zoom. Audio recordings were transcribed, reviewed, and saved with anonymization of speaker identities. NVivo software was used to facilitate content analysis and identify key themes. The nurses' rate of "Oral Health Education" comments statistically exceeded that of teachers, while teachers had higher rates for "Parental Involvement" and "Mutual Perception" "Need for Care" was perceived to be more prevalent in immigrants to the United States based on student behaviors and complaints. "Access to Care" was seen as primarily the nurse's role. Strong relationships between community clinics and schools were viewed by some as integral to students achieving good oral health. The results suggest dimensions and questions important to item development for oral health surveys of children and parents to address screening, management, program assessment, and policy planning.
\end{abstract}

Keywords: focus group; patient reported outcome measures; oral health; education; COVID-19; dental problem

\section{Introduction}

The 2021 NIH Report on Oral Health provides a roadmap to improve the nation's oral health, noting that dental caries is one of the most common diseases of childhood [1]; consequently, the report promotes oral health interventions and improved access to dental care for young children to promote oral health across the lifespan. Patient-Reported Outcomes (PROs) can be used to assess oral health and evaluate the impact of dental care [2]. The Patient-Reported Outcomes Measurement Information System (PROMIS ${ }^{\circledR}$ ) includes reliable, valid and efficient patient-reported measures for a wide range of chronic diseases and demographic characteristics to evaluate medical interventions [3,4]. However, $P R O M I S^{\circledR}$ item banks, as tools to assess outcomes, are just beginning to target children's oral health. 
Qualitative methods include focus groups and interviews [5,6]. Qualitative research emphasizes "grounded" concepts and theories [7]. To achieve a grounded approach, we used nurses and teachers as knowledgeable informants [6,8].

Oral health education can be integrated into the school routine, promoting students' knowledge of oral health conditions and oral hygiene habits $[9,10]$. Teachers and school nurses have unique perspectives about oral health education, promotion of student oral health, and oral health literacy of parents and caregivers. With increasing frequency, teachers and nurses provide education programs to improve children's understanding of their oral conditions and good dental habits [11-13]. To foster these efforts, teachers' oral health-related knowledge, attitudes, and practices need to be strengthened [14-16]. Continuing education and in-service training are critical for school nurses who, as the health professionals in their schools, play an essential role in oral health promotion [17-19].

Perceptions and practices of teachers and school nurses are changing due to available dental resources, advanced technologies, and remote teaching, especially during the COVID-19 pandemic [20,21]. A survey of pediatric dentists in Germany found only onefifth of the dental clinics were fully functional during the first lockdown, with two-thirds of respondents reporting that oral hygiene appointments and regular dental check-ups were postponed [22]. Remote consultations and digital photographs were used as an alternative way to screen patients by the pediatric dental emergency service to minimize unnecessary emergency visits [21,23].

Traditional focus group discussions involve face-to-face interactive group settings and usually experience barriers such as participant dropout and financial costs. There is increased attention toward utilizing online environments to facilitate aspects of focus group discussions. More and more studies employed an entirely virtual process to focus group research, from recruitment to facilitation and reimbursement [24-27].

The purpose of this qualitative research study is to elicit nurses' and teachers' perceptions of school-aged children's and adolescents' oral health status and reflect on their experiences with students and parents.

\section{Materials and Methods}

\subsection{Recruitment of Participants}

Nurses and teachers were recruited from three school levels including elementary, middle, and high schools across Los Angeles County. The school sites were selected across all eight Service Planning Areas (SPAs) [28]. Participants were contacted between May and July 2021 via multiple sources such as previous school connections, e-mail groups, and referrals. A flyer with a description of the study objective, procedure, and incentive was e-mailed to the potential participants. The potential participants completed a HIPAAcompliant Google Form to provide information such as school name(s), school district, grade, gender, and race/ethnicity. All participants were required to speak English and currently work in at least one school site. The participants received a \$50 Amazon e-gift card upon finishing the interviews. All subjects gave their informed consent for inclusion before they participated in the study. The study was conducted in accordance with the Declaration of Helsinki, and the protocol was approved by the Ethics Committee of the Office of Human Research Protection Program, University of California, Los Angeles (Project identification code 20-000719). The research team has previous studies of children's oral health [29-31]. The work reported here is presented according to the recommendations of Standards for Reporting Qualitative Research (SRQR), as listed in Appendix A [32].

\subsection{Focus Group Interviews}

We conducted and recorded three one-hour focus group interviews for teachers at three school levels separately, and another three for school nurses, via Zoom, a HIPAAcompliant online meeting platform [33]. Each meeting was scheduled for a time in the late 
afternoon or early evening from June to July 2021 and included three-to-six participants in each session, with an invitation and multiple reminders sent to six-to-ten potential participants. The discussions were guided by a moderator, an observer, and at least one assistant moderator. Interviews were performed based on a two-stage framework with a schedule of questions drafted by two experts in the field of children's oral health covering: students' need for and access to care, referrals to dental providers or community clinics, oral health education, parental involvement, mutual perceptions of teachers and nurses, and the use of remote technology in teaching and school nursing practice. In the first stage, the moderator led an open discussion for each question around participants' experiences with students' oral health. The second stage further allowed participants to delve deeper into specific areas, followed up by questions posed by the observer at the end of the discussion. The questions, sub-questions, and prompts guiding the discussion are shown in Appendix B.

Before starting the recording of each session, participants provided their audio consents and were given a participant ID to assure anonymity during the whole session. Participants' focus group comments and background information were linked using the assigned participant ID. Data collection included audio recordings, focus group transcripts, and moderator comments. To assure the confidentiality and protection of participants, audiotaping and audio recordings were only accessed by the research team.

\subsection{Analysis}

Each focus group was digitally recorded and transcribed verbatim and entered into NVivo (Release 1.0) Version 13, a qualitative text analysis database [34]. Frequencies and content analysis of the focus group transcript, including thematic and narrative analyses, were used to uncover themes. The frequency of mentions pertaining to specific themes, for example, provided a sense of what nurses and teachers viewed as important. We reviewed the constructs within each focus group; reviewed the total data set to identify promising thematic domains; grouped responses according to these thematic domains; and then finalized a set of six key themes. We examined how these themes supported the data, and our primary theoretical perspective, namely students' oral health status, and then determined the frequency of mentions, or expressed concerns, for each theme by occupational role. The comparison between school nurses and teachers has been compared using a Chi-square test with a significance level of 0.05 [35]. The broad issues explored in the discussions were classified as "coding nodes" to document the frequency of expressed concerns related to a particular theme or topic and to analyze relationships between these concerns based on the respondents. Within each coding node, specific content was coded as pertinent to more general and/or more particular issues to allow for multi-level analysis.

\section{Results}

\subsection{Participants}

Six focus groups were conducted: three for the school nurses $(n=14)$ and three for teachers $(n=15)$. The self-reported demographic information is summarized as shown in Table 1. Most participants were female with $100 \%$ of school nurses and $67 \%$ of teachers identifying as female. In addition to three participants who preferred not to disclose their race and ethnicity, over one-third of school nurses were Hispanic (36\%), with 21\% identifying as White and another $21 \%$ as Asian. Most of the teachers were Hispanic (27\%) and African American (27\%). To be more representative, we recruited participants from different school types, including eight private, seven public general, five public magnet, and four public charter schools. Since some of the schools shared one school nurse, another four district nurses were interviewed. More details about participants from different school types are presented in Table 1. 
Table 1. Characteristics of Nurses and Teachers by Session

\begin{tabular}{|c|c|c|c|c|c|c|c|c|c|}
\hline \multirow[b]{2}{*}{ Characteristics } & \multicolumn{4}{|c|}{$\begin{array}{c}\text { Nurses: } \mathrm{N}=14 \\
\text { n (\%) }\end{array}$} & \multicolumn{4}{|c|}{$\begin{array}{c}\text { Teachers: } \mathrm{N}=15 \\
\text { n (\%) }\end{array}$} & \multirow[b]{2}{*}{ Total } \\
\hline & $\begin{array}{c}\text { Elementary } \\
\text { School }\end{array}$ & $\begin{array}{l}\text { Middle/ } \\
\text { High } \\
\text { School }^{1}\end{array}$ & $\begin{array}{l}\text { High } \\
\text { School }\end{array}$ & Total & $\begin{array}{c}\text { Elementary } \\
\text { School }\end{array}$ & $\begin{array}{l}\text { Middle } \\
\text { School }\end{array}$ & $\begin{array}{l}\text { High } \\
\text { School }\end{array}$ & Total & \\
\hline No. of Participants & $\begin{array}{c}6 \\
(100 \%)\end{array}$ & $\begin{array}{c}5 \\
(100 \%)\end{array}$ & $\begin{array}{c}3 \\
(100 \%)\end{array}$ & $\begin{array}{c}14 \\
(100 \%)\end{array}$ & $\begin{array}{c}5 \\
(100 \%)\end{array}$ & $\begin{array}{c}5 \\
(100 \%)\end{array}$ & $\begin{array}{c}5 \\
(100 \%)\end{array}$ & $\begin{array}{c}15 \\
(100 \%)\end{array}$ & $\begin{array}{c}29 \\
(100 \%)\end{array}$ \\
\hline \multicolumn{10}{|l|}{ Gender } \\
\hline Female & $\begin{array}{c}6 \\
(100 \%)\end{array}$ & $\begin{array}{c}5 \\
(100 \%)\end{array}$ & $\begin{array}{c}3 \\
(100 \%)\end{array}$ & $\begin{array}{c}14 \\
(100 \%)\end{array}$ & $\begin{array}{c}4 \\
(80 \%)\end{array}$ & $\begin{array}{c}3 \\
(60 \%)\end{array}$ & $\begin{array}{c}3 \\
(60 \%)\end{array}$ & $\begin{array}{c}10 \\
(66.7 \%)\end{array}$ & $\begin{array}{c}24 \\
(82.8 \%)\end{array}$ \\
\hline Male & $\begin{array}{c}0 \\
(0 \%) \\
\end{array}$ & $\begin{array}{c}0 \\
(0 \%) \\
\end{array}$ & $\begin{array}{c}0 \\
(0 \%) \\
\end{array}$ & $\begin{array}{c}0 \\
(0 \%) \\
\end{array}$ & $\begin{array}{c}1 \\
(20 \%) \\
\end{array}$ & $\begin{array}{c}2 \\
(40 \%) \\
\end{array}$ & $\begin{array}{c}2 \\
(40 \%) \\
\end{array}$ & $\begin{array}{c}5 \\
(33.3 \%) \\
\end{array}$ & $\begin{array}{c}5 \\
(17.2 \%) \\
\end{array}$ \\
\hline Race / Ethnicity & & & & & & & & & \\
\hline $\begin{array}{l}\text { Hispanic/ } \\
\text { Latinx }\end{array}$ & $\begin{array}{c}2 \\
(33.3 \%)\end{array}$ & $\begin{array}{c}3 \\
(60 \%)\end{array}$ & $\begin{array}{c}0 \\
(0 \%)\end{array}$ & $\begin{array}{c}5 \\
(35.7 \%)\end{array}$ & $\begin{array}{c}2 \\
(40 \%)\end{array}$ & $\begin{array}{c}1 \\
(20 \%)\end{array}$ & $\begin{array}{c}1 \\
(20 \%)\end{array}$ & $\begin{array}{c}4 \\
(26.7 \%)\end{array}$ & $\begin{array}{c}9 \\
(31.0 \%)\end{array}$ \\
\hline $\begin{array}{l}\text { White/ } \\
\text { Caucasian }\end{array}$ & $\begin{array}{c}2 \\
(33.3 \%)\end{array}$ & $\begin{array}{c}1 \\
(20 \%)\end{array}$ & $\begin{array}{c}0 \\
(0 \%)\end{array}$ & $\begin{array}{c}3 \\
(21.4 \%)\end{array}$ & $\begin{array}{c}1 \\
(20 \%)\end{array}$ & $\begin{array}{c}0 \\
(0 \%)\end{array}$ & $\begin{array}{c}2 \\
(40 \%)\end{array}$ & $\begin{array}{c}3 \\
(20 \%)\end{array}$ & $\begin{array}{c}6 \\
(20.7 \%)\end{array}$ \\
\hline $\begin{array}{l}\text { Asian/Asian } \\
\text { American }\end{array}$ & $\begin{array}{c}1 \\
(16.7 \%)\end{array}$ & $\begin{array}{c}1 \\
(20 \%)\end{array}$ & $\begin{array}{c}1 \\
(33.3 \%)\end{array}$ & $\begin{array}{c}3 \\
(21.4 \%)\end{array}$ & $\begin{array}{c}1 \\
(20 \%)\end{array}$ & $\begin{array}{c}1 \\
(20 \%)\end{array}$ & $\begin{array}{c}1 \\
(20 \%)\end{array}$ & $\begin{array}{c}3 \\
(20 \%)\end{array}$ & $\begin{array}{c}6 \\
(20.7 \%)\end{array}$ \\
\hline $\begin{array}{l}\text { Black/African } \\
\text { American }\end{array}$ & $\begin{array}{c}0 \\
(0 \%)\end{array}$ & $\begin{array}{c}0 \\
(0 \%)\end{array}$ & $\begin{array}{c}0 \\
(0 \%)\end{array}$ & $\begin{array}{c}0 \\
(0 \%)\end{array}$ & $\begin{array}{c}1 \\
(20 \%)\end{array}$ & $\begin{array}{c}2 \\
(40 \%)\end{array}$ & $\begin{array}{c}1 \\
(20 \%)\end{array}$ & $\begin{array}{c}4 \\
(26.7 \%)\end{array}$ & $\begin{array}{c}4 \\
(13.8 \%)\end{array}$ \\
\hline $\begin{array}{l}\text { American } \\
\text { Indian/Alaskan } \\
\text { Native }\end{array}$ & $\begin{array}{c}0 \\
(0 \%)\end{array}$ & $\begin{array}{c}0 \\
(0 \%)\end{array}$ & $\begin{array}{c}0 \\
(0 \%)\end{array}$ & $\begin{array}{c}0 \\
(0 \%)\end{array}$ & $\begin{array}{c}0 \\
(0 \%)\end{array}$ & $\begin{array}{c}1 \\
(20 \%)\end{array}$ & $\begin{array}{c}0 \\
(0 \%)\end{array}$ & $\begin{array}{c}1 \\
(6.7 \%)\end{array}$ & $\begin{array}{c}1 \\
(3.4 \%)\end{array}$ \\
\hline Prefer not to say & $\begin{array}{c}1 \\
(16.7 \%)\end{array}$ & $\begin{array}{c}0 \\
(0 \%)\end{array}$ & $\begin{array}{c}2 \\
(66.7 \%)\end{array}$ & $\begin{array}{c}3 \\
(21.4 \%)\end{array}$ & $\begin{array}{c}0 \\
(0 \%)\end{array}$ & $\begin{array}{c}0 \\
(0 \%)\end{array}$ & $\begin{array}{c}0 \\
(0 \%)\end{array}$ & $\begin{array}{c}0 \\
(0 \%)\end{array}$ & $\begin{array}{c}3 \\
(10.3 \%)\end{array}$ \\
\hline School Type & & & & & & & & & \\
\hline Private School & $\begin{array}{c}1 \\
(16.7 \%)\end{array}$ & $\begin{array}{c}3 \\
(60 \%)\end{array}$ & $\begin{array}{c}0 \\
(0 \%)\end{array}$ & $\begin{array}{c}4 \\
(28.6 \%)\end{array}$ & $\begin{array}{c}1 \\
(20 \%)\end{array}$ & $\begin{array}{c}3 \\
(60 \%)\end{array}$ & $\begin{array}{c}0 \\
(0 \%)\end{array}$ & $\begin{array}{c}4 \\
(26.7 \%)\end{array}$ & $\begin{array}{c}8 \\
(27.6 \%)\end{array}$ \\
\hline Public General School & $\begin{array}{c}2 \\
(33.3 \%)\end{array}$ & $\begin{array}{c}0 \\
(0 \%)\end{array}$ & $\begin{array}{c}0 \\
(0 \%)\end{array}$ & $\begin{array}{c}2 \\
(14.3 \%)\end{array}$ & $\begin{array}{c}2 \\
(40 \%)\end{array}$ & $\begin{array}{c}1 \\
(20 \%)\end{array}$ & $\begin{array}{c}1 \\
(20 \%)\end{array}$ & $\begin{array}{c}4 \\
(26.7 \%)\end{array}$ & $\begin{array}{c}6 \\
(20.7 \%)\end{array}$ \\
\hline Public Magnet School & $\begin{array}{c}0 \\
(0 \%) \\
\end{array}$ & $\begin{array}{c}0 \\
(0 \%) \\
\end{array}$ & $\begin{array}{c}2 \\
(66.7 \%) \\
\end{array}$ & $\begin{array}{c}2 \\
(14.3 \%) \\
\end{array}$ & $\begin{array}{c}0 \\
(0 \%) \\
\end{array}$ & $\begin{array}{c}1 \\
(20 \%) \\
\end{array}$ & $\begin{array}{c}3 \\
(60 \%) \\
\end{array}$ & $\begin{array}{c}4 \\
(26.7 \%)\end{array}$ & $\begin{array}{c}6 \\
(20.7 \%) \\
\end{array}$ \\
\hline Public Charter School & $\begin{array}{c}0 \\
(0 \%) \\
\end{array}$ & $\begin{array}{c}1 \\
(20 \%) \\
\end{array}$ & $\begin{array}{c}1 \\
(33.3 \%) \\
\end{array}$ & $\begin{array}{c}2 \\
(14.3 \%) \\
\end{array}$ & $\begin{array}{c}2 \\
(40 \%) \\
\end{array}$ & $\begin{array}{c}0 \\
(0 \%) \\
\end{array}$ & $\begin{array}{c}1 \\
(20 \%) \\
\end{array}$ & $\begin{array}{c}3 \\
(20 \%) \\
\end{array}$ & $\begin{array}{c}5 \\
(17.2 \%) \\
\end{array}$ \\
\hline District ${ }^{2}$ & $\begin{array}{c}3 \\
(50 \%)\end{array}$ & $\begin{array}{c}1 \\
(20 \%)\end{array}$ & $\begin{array}{c}0 \\
(0 \%)\end{array}$ & $\begin{array}{c}4 \\
(28.6 \%)\end{array}$ & $\begin{array}{c}0 \\
(0 \%)\end{array}$ & $\begin{array}{c}0 \\
(0 \%)\end{array}$ & $\begin{array}{c}0 \\
(0 \%)\end{array}$ & $\begin{array}{c}0 \\
(0 \%)\end{array}$ & $\begin{array}{c}4 \\
(13.8 \%)\end{array}$ \\
\hline
\end{tabular}

${ }^{1}$ A mixed session with nurses from both middle and high schools.

${ }^{2}$ Nurses can work at multiple school sites at different education levels in one district. They participated in only one session. 


\subsection{School Nurse and Teacher Responses}

Overarching issues included: 1) students' needs for oral health treatment and access to needed services, 2) concern for the oral health needs of "newcomers," namely students off recent U.S. immigrant and refugee families; and 3) challenges to parents' involvement in their children's oral health concerns while advancing various approaches to enhance parental engagement in attending to them.

Table 2 provides data on the distribution of nurses' and teachers' comments for the six key themes: need for care, access to care, referrals, oral health education, parental involvement, and mutual perceptions of nurses' and teachers' roles in students' oral health concerns. Each theme consists of positive and negative codes. This table presents 1) the frequency of comments related to each theme and the number of comments per nurse or teacher; and 2) the number of nurses or teachers who made one or more comments containing the thematic code, and the proportion of respondents within the group.

Table 2. Frequency of Mentions, by Teacher and Nurse Respondents, for the Key Themes

\begin{tabular}{|c|c|c|c|c|c|c|c|c|c|c|}
\hline \multirow{3}{*}{ Themes } & \multicolumn{5}{|c|}{ Frequency of Comments } & \multicolumn{5}{|c|}{ Frequency by Respondents } \\
\hline & \multicolumn{2}{|c|}{$\begin{array}{l}\text { School Nurses } \\
\qquad(\mathbf{N}=14)\end{array}$} & \multicolumn{2}{|c|}{$\begin{array}{l}\text { Teachers } \\
(\mathrm{N}=15)\end{array}$} & \multirow[t]{2}{*}{ p-value ${ }^{3}$} & \multicolumn{2}{|c|}{$\begin{array}{l}\text { School Nurses } \\
\qquad(\mathrm{N}=14)\end{array}$} & \multicolumn{2}{|c|}{$\begin{array}{l}\text { Teachers } \\
(\mathrm{N}=15)\end{array}$} & \multirow[t]{2}{*}{ p-value ${ }^{3}$} \\
\hline & $\mathbf{n}$ & Rate $^{1}$ & $\mathbf{n}$ & Rate $^{1}$ & & n & Rate $^{2}$ & $\mathbf{n}$ & Rate $^{2}$ & \\
\hline Need for Care & 25 & 1.79 & 33 & 2.20 & NS & 10 & 0.71 & 13 & 0.87 & NS \\
\hline Access to Care & 36 & 2.57 & 25 & 1.67 & NS & 11 & 0.79 & 13 & 0.87 & NS \\
\hline Referrals & 14 & 1.00 & 8 & 0.53 & NS & 12 & 0.86 & 7 & 0.47 & NS \\
\hline $\begin{array}{l}\text { Oral Health Ed- } \\
\text { ucation }\end{array}$ & 24 & 1.71 & 10 & 0.67 & $<0.01^{* *}$ & 9 & 0.64 & 4 & 0.27 & NS \\
\hline $\begin{array}{l}\text { Parental In- } \\
\text { volvement }\end{array}$ & 29 & 2.07 & 56 & 3.73 & $<0.01^{* *}$ & 13 & 0.93 & 15 & 1.00 & NS \\
\hline $\begin{array}{l}\text { Mutual Percep- } \\
\text { tions }\end{array}$ & 2 & 0.14 & 14 & 0.93 & $<0.01^{* *}$ & 2 & 0.14 & 11 & 0.73 & $0.02^{*}$ \\
\hline \multicolumn{11}{|c|}{$\begin{array}{l}{ }^{2} \text { Rate }=\text { Number of Respondents / Total Number of Participants } \\
{ }^{3} \text { Chi-square Test [35] }\end{array}$} \\
\hline
\end{tabular}

The most frequent comments by nurses concerned "Access to Care" ( $n=35)$ and the least frequent responses were two comments on "Mutual Perceptions," made by nurses about teachers and vice versa, while the most frequent comments made by teachers concerned "Parent Involvement" $(n=56)$ and the least concerned "Referrals" $(n=8)$. There was a statistically significant difference $(p$-value $<0.01)$ between nurses and teachers regarding the number of comments on "Oral Health Education" (rates 1.71 vs 0.67), "Parental Involvement" (rates 2.07 vs 3.73), and "Mutual Perceptions" (rates 2.07 vs 3.73). Most nurses responded to all except for "Mutual Perceptions," which was mentioned by only two respondents. Teachers also responded at relatively high rates except for "Referrals" (rate $=0.47$ ) and "Oral Health Education" (rate =0.27). "Mutual Perceptions" was the only theme that was statistically significant $(\mathrm{p}$-value $=0.02)$. Table 3 provides quotes to illustrate how these themes are expressed in the teachers' and nurses' own words. All quotations cited in the text are those of focus group participants. 
Table 3. Representative Comments for Key Themes

Themes

\section{Need for Care}

think, that comes along with that, where they won't open their
mouth, or they won't smile only because they know that they
are lacking oral hygiene and care.

Middle School Nurse: But a lot of these children are coming from other countries where they have other physical impairments, orthopedic impairments, things like that and oral health is not a priority for them...There's some shame also, I

\section{Nurses}

Elementary School Nurse: When they come in with mouth pain, I have them rinse their mouth. I do have them floss...I also tell them that you know they're going to end up getting an infection and it's going to go to their heart.

\section{Representative Comments}

Access to Care

Middle School Nurse: We do have access to a lot of services; the mobile services are limited, varnish, fluoride treatments, screening and then, if there are severe diseases or things that can't be done in a mobile setting then we refer them out. Part of the issue is a lot of it is also, for at least our demographic, a lot of education that's needed around oral health sometimes. The family is aware that the child has oral health needs, but just doesn't understand the importance of dental care and what could potentially happen if they don't get that treated immediately. And the other thing is, we do have a lot who are fearful of whether it's their immigration status or their financial status or if their MediCal or DentalCal. There's that fear that
Teachers

High School Teacher: So, I've known students who, bay don't s and when they laugh, they try to purposely coverup, so they'll keep their mouth closed. But then, from students I've known, they'll get braces and, afterward, once they're done with the braces, suddenly, they start smiling again. So, and I talked about this before, about how they were embarrassed about their teeth and, you know, until they got the braces and their teeth were straightened; now, then, afterward, they smile differently.

High School Teacher: With a lot of our newcomers that are coming from El Salvador, Guatemala, Nicaragua, Colombia, Mexico, especially from Central and South America, many of them are coming. with zero dental oral health services in their lives, and so it, you know, especially that population, has struggled and then, you know, come here and then really needs a full workup analysis, I don't know what dentists call it, but, you know, some indication.

Middle School Teacher: The health clerk checks them out and usually contacts parents and if they don't get ahold of parents, I usually like to follow up, especially with my special population because that's the experience I've had that they're the same kids that are constantly having the same issues. The first one, that I had in mind, you know, he was always saying you know, he was always hungry and always complaining of the toothache, so we had to call the guardians more than once to be able to reach them. But sadly, in his case, we had to get social services involved because there was clear neglect with him, unfortunately.

High School Teacher: Yes, in my previous school that I was at for eight years, the majority of my students in my program were from the group home and our justice system and so forth, so there were lots of issues with consistency as far as their oral hygiene was concerned So, certainly, there is the aspect that the students were in pain from dental issues and the group home did make phone calls and appointments for the students to see a dentist. 
they will still be financially responsible so they're not willing to seek the resources out of fear, so we find that we have to do a lot of education with our students and our families.

Elementary School Nurse: In my district, we use a dental school and also use an in-school dental program and they come to this school but, like you said two-three days only; they see students in three sessions; they wait in lines to be seen. They can do X-rays, fluoride treatments, and those who don't have insurance, receive only cleaning and they put the fluoride. They tell the parents to take their child to the doctor at the dental school who does the treatment...So, I refer them to the ones that cover MediCal, because the majority of these kids have MediCal. So, I refer them to the closest one where they live. Sometimes when I screen, I scare them. They have a lot of

Referrals scary mouths in my area, so. I refer them to the doctor, who sometimes asks why the child has not been a dentist.

Middle School Nurse: We do see a lot of students with caries or even ones that need braces and don't have access to it, so in those instances, first of all, make contact with the family, with a parent; see what kind of insurance or lack of insurance they have; what kind of access. If they need resources, we'll be for them; we're fortunate that we have some school-based clinics. We do have mostly volunteers who work, and then we also have mobile oral health programs that visit our school sites or that we can refer students to.

Middle School Nurse: I work with the main teacher that teaches that health course who provided kind of the material to me, and then we added to that with online resources and things like that, and then formal training I'd say nursing school does touch on oral hygiene, especially in pediatrics rotation and then I can say for myself my community health rotation was at a free clinic where we actually worked alongside dentists, and I did dental hygiene work as a nursing student as well, so in that

Oral Health

Education sense, I got to, you know, kind of hopefully work in a space with a dentist and be in that same space.

Middle School Nurse: I didn't have any formal training, but I have a good relationship with one of the parents there who happens to be a dentist. So, any questions I have, I always refer to him, and then, when I do teach a health class, it is material that has been passed down to me from the previous teacher and I usually just focus on dental hygiene, the, you know, the
Middle School Teacher: We don't have a school nurse, but because we're a community school, we have a lot of different referrals. So, we were able to refer them out to different programs. We also work closely with a local clinic, which is a free clinic and then in our community, which is there for them as well and we're close to a dental school, so we usually refer them to those two places.

High School Teacher: The kids who are in group homes, the kids who are part of the juvenile justice system; those kids often struggle with oral health issues and oftentimes cannot get dental appointments. Part of the reason why, you know, we set up a partnership with a dental school, so that that we could get some dentists to come out and try to provide at least some screening and what not for some of our students who are not yet at least, in our case, in the group homes and the juvenile justice system, which are not necessarily making the appointments for them. And so, sometimes these kids are, you know, they'll come, and they'll say, you know, I'm in pain and you know, and then we'll try to hook them up with a dentist or at least, you know, a local clinic that can at least provide some level of support.

Elementary School Teacher: We don't really teach oral hygiene and oral health is for dentists. I think it's left up to the parents and my experience in the past has been that schools have been involved with bringing a dentist in giving them a personal lesson on what to do, how to encourage them to know how to brush their teeth after eating, making sure that that's done.

High School Teacher: We are lucky enough in my area to have a clinic, that is, you know, a very, very generous clinic that helps our students and this clinic, actually, they present to our students through elementary school, and they try to get to middle school and high school. So, you know, I even have this group come in and present too, so we talked a lot about, you know, dental care and basic hygiene and how important it is for our health in general that, you know, you 
important part of it, the name of the teeth and washing and why it's important but also what I see when the kids come in with any dental problems I'll have an example about that, and why it got to that point and what to do after.

Elementary School Nurse: Another nurse came up with an amazing plan, where she would set up a table in the morning with the puppets and with the different dental materials. Then, as parents were dropping off kids, that's another way to get the parents to sign consents because the afterschool program doesn't reach the parents that are the stay-at-home moms that do not have their kids in after-school programs. Also, present visuals that everyone would just be curious about: the cute dinosaurs and also have giveaways at that table that you give out. It's not even about toothbrushes you give out. They did the best job of engaging parents that I had ever seen.

High School Nurse: A lot of the schools have an active place
Parental

Involvement where parents can gather and share resources and, on my campus, we have a parent representative who oversees the parent center and interacts with parents. So, you asked how we can get the parents involved: create awareness, be invested in or oversee, you know, supervising their children's health. I would say that's a really good avenue to tap into and if there are agencies for programs where they want to provide, you know, education, like seminars, a demo of good oral hygiene, health and how to do that. I mean, even at the high school level, you know high schoolers are lazy. You know and unless it's drilled in, something that they do on their own, they're going to neglect that so and then, if I mean oral hygiene, I think, is always tied into nutrition so. You know, combining that with your basics good nutritious eating and at the high school well that's a problem because kids don't eat and they don't choose nutritious foods and so that ties back into getting, you know, caries and all that stuff so.

Elementary School Nurse: You know, I have tried to teach some teachers. The thing is we lack supplies, like toothbrushes and then just to actually teach the kids, because that's what I

Mutual had mentioned. I want to do a group of my teachers at my Perceptions school. I remember back in the day, they used to be like when everyone came back from lunch, they used to say, "brush your teeth." Just teaching those healthy habits at a young age. I tried to do that, but it was just a lack of supplies, lack of resources, could have numerous health problems, just because your teeth are not, you know, healthy.

Elementary School Teacher: I'd keep it small only because you'll have parents that maybe don't feel like they can chat; maybe their English isn't strong, if you know, maybe they didn't get it; they might not even be speaking Spanish, they might speak another language...We see this with a lot of second language families, where they're so capable, but because they're not strong in English, they don't volunteer to help out at the school. And they can give so much to our school, so you'll see this also where they won't share; so maybe have something after where they can, I don't know, where they can talk some, you know e-mail or do something that they can continue after, because a lot of them will just sit there and smile, but they have a lot to say; you just won't know it, we see that a lot.

Elementary School Teacher: I would just say you're going to get a higher rate of attendance on Zoom; that's what I've noticed, especially with conferences. For parents who have a hard time at lunch break to drive all the way down to school, Zoom has made it so much easier to communicate. So, I think people are going to be, especially parents are going to be, much more open to doing a meeting knowing they don't need to drive somewhere, find parking and find a babysitter and such.

High School Teacher: Our school nurse is absolutely fabulous. She is most of the time at our school. She's the head nurse for the district, so she spends a lot of time at our school, but there are health assistants. She has health assistants and then she also has nurses in training that come in and they are fabulous; they are wonderful; they're very receptive to any issues that we have on campus. So, I definitely wouldn't have any problem referring a student 
so it hasn't been done, but teachers are receptive. But it's not something you know they can afford.

Middle School Nurse: As with other health issues, the teacher always is the first one to figure out something is wrong because they're the ones with students almost every single minute at school. We are like, "whenever they find the problems... well, send them to us," so our teachers will definitely help a lot. down to the nurse, but I also wouldn't have any problem referring a student to our, you know, clinic in the area that could help out.

High School Teacher: We do have a full-time school nurse, and I have the absolute opposite experience. She often sends kids back immediately and won't even call home if they're sick. They pretty much go to her with whatever their ailment is, and she gives them an ice pack and sends the student back to class. That's correct, and then to give her a little credit, we do have a high population of students with significant disabilities, so she does, you know, help supervise with toileting for some of the kids. Or some of our students receive medication through the day and things like that, but overall, just the general student coming in with any kind of problem, they're not going to get any help through the nurse's office. They are more likely to get help if we send them to their academic counselor.

Need for Care - Teachers noted how students moved from being embarrassed about their teeth, appearing reticent about smiling, purposely covering their faces, and keeping their mouths tightly closed, to becoming open and smiling once they received dental treatment, including braces. Teachers expressed concern for the many students from new immigrant families, especially from Central and South America where there were limited resources for the poor, stating that, once they came to this country, it was often the first time that these students encountered a dental professional. Nurses acknowledged the same, claiming that many newcomers present with other physical disabilities that will often place oral health treatment at a lower priority for parents. Often frustrated in their efforts to influence a parent to follow up on their referrals for a child with oral pain, some nurses employed fear arousal, stating that left untreated, infections in the oral cavity may place their children at risk for other physical ailments.

Access to Care - Teachers stated that they are typically the first to recognize a dental problem and send the student to the nursing office. Sometimes, a child will have recurrent dental problems, especially those from special populations, including the child welfare and juvenile justice systems, where there may be limited follow-up by guardians or family caregivers. In such cases, teachers enlisted social services to assure access to needed treatment. Nurses spoke about assuring access, even for immigrant or refugee students, by advocating parents to register their children for Medicaid services. Even with this push for increased access to dental care, nurses acknowledged the need to increase parents' oral health literacy, conveying the importance of seeking immediate care for untreated conditions that may affect their child's learning. Teachers and nurses agreed that students are more likely to have poor oral health if they are low-income, uninsured, members of a racial or ethnic minority, or are from immigrant families.

Referrals - Teachers expressed gratitude for the availability of low-cost dental resources in community and local dental school clinics. Despite this, many addressed concerns about students from "newcomer" families, those in group homes, or the juvenile justice system, where there were many barriers to scheduling and keeping appointments once a referral was made. Nurses viewed the contractual arrangements between local dental schools and third-party in-school dental programs as facilitating their referrals. Most had listings of low-cost community resources to refer students for needed treatment and 
found that parents were receptive to the dental staff's recommendations and satisfied with the care their children received.

Oral Health Education - Teachers rarely viewed themselves as health educators, viewing oral hygiene and prevention as best left to dentists and clinics with contractual agreements with their schools. Some teachers were grateful for the clinic representatives that present to students, across the grades, on daily oral hygiene and regular dental care. Nurses talked about their limited formal training in oral care when in nursing school, though some expressed how they learned from both teachers who taught health classes and online courses. Some nurses have even learned sufficient content to work with teachers and lead in instructing the oral hygiene class.

Parental Involvement - Teachers expressed challenges in communicating in the various languages, including indigenous dialects, prevalent in their school communities. Despite such language barriers, they recognized the importance and willingness of many non-English-speaking parents to participate in their children's learning. Other teachers pointed to potential barriers that limit parental involvement, notably fears about disclosure of the families' legal status, and defensiveness about their long working hours that hinder the ability to fully participate in their child's schooling. Teachers appeared positive about the use of remote technology platforms to engage parents and facilitate communication, by visually sharing what their children are learning in class. While school nurses have used remote technology in reaching parents, they preferred face-to-face parent meetings to share resources, suggesting working with parent centers and their representatives as the best way to increase such interactions. Nurses were concerned that certain parents do not respond to their calls regarding the child's pain, noting that even when they do call back, some appeared unable to handle the matter themselves, viewing the nurse as the expert best suited to manage their child's health needs.

Mutual Perceptions - The teachers' comments regarding nurses represent extremes, ranging from praise to criticism of their performance. While some teachers expressed concerns about part-time nurses' availability, others recognized the school nurse's ability to interact with parents and serve as a resource for referral to community services. Nurses regarded teachers as an effective resource to alert them to students' oral health concerns because of their ongoing contact with students. While some nurses said that the inability to provide oral hygiene supplies to classrooms precluded their engagement with teachers in an oral health activity, others worked with teachers to incorporate oral health as part of required health classes.

\section{Discussion}

School nurses and teachers from elementary, middle, and high schools amid the COVID pandemic conveyed their insights into students' oral health and the challenges these professionals face while working in diverse school communities. All commented about challenges with involving parents in their children's educational and health concerns, although teachers expressed almost twice as many comments as did nurses. The pandemic necessitated them to interact with parents, though parents' suboptimal responses exacerbated their frustrations, sometimes to the point of alienation. Teachers had much to say about the nurses' involvement with their students. Most comments were laudatory, however, some teachers expressed frustration with nurses' lack of attention to their students' oral health needs. Other teachers mentioned that their schools did not even employ nurses. Nurses also expressed frustration, notably that the considerable time necessary to conduct required hearing and eye examinations impinged upon their ability to address students' oral health problems. Nurses were more involved in oral health education than were teachers, while neither group felt sufficiently trained to conduct such programs.

Focus group participants noted that the pandemic required using remote technology to teach, educate, evaluate, and communicate with parents and students. Nursing's traditional role of providing face-to-face contact with students and parents was conducted in 
a medium that required separation, as remote technologies were commonly relied upon. Teachers often competed with nurses to remotely access children and their parents. Parents raising families in crowded homes, with uncertain language skills, and multiple jobs, may feel impinged upon, while other parents may welcome this modality because of the convenience of not having to travel to school to meet with teachers or nurses. When the pandemic subsides and as children return to school, the technology's impact is expected to alter in overt or subtle ways the roles of everyone engaged in the educational process and, based upon lessons learned, may enhance the oral health presence.

The need for effective oral health interventions is particularly important because it links dental schools to K-12 educational settings in partnerships that can provide educational opportunities for dental student involvement in community-based care. The underlying sense is that there is a gap between what is being done in schools to enhance oral health programs and referral networks for needed services through engaging nurses and teachers in oral health education and advocacy, and the establishment of broader-based coalitions on behalf of students' oral health needs. Such partnerships between the K-12 schools, dental schools, and dental providers in the community are key to assuring targeted advocacy efforts for access to needed services. In Los Angeles, a nonprofit organization used key informants and focus groups to organize and activate a community coalition to fund a district-wide health nurse program to implement a school-based intervention with an array of services including screenings, fluoride applications, and referrals [36]. Another effort advocated for school nurses to promote the oral health of children and families, including specific actions and oral health information [37].

There are certain benefits to remote focus groups. First, this modality saves time and money associated with travel for both the researcher and the participant within these virtual settings [25]. Second, the remote techniques allow simultaneous participation across a wide geographic area, providing the potential for geographically diverse participants [24]. Third, remote focus groups provide an anonymous and comfortable environment to assess sensitive experiences, particularly for marginalized populations who may be unwilling to participate in face-to-face focus groups [26]. At the same time, remote focus groups have the disadvantages of the lack of face-to-face interaction, connectivity issues, and technical missteps. Besides, it is difficult for some participants to find a quiet and private place with minimal disruptions [27]. Beyond these generalized limitations, our study is limited to a small group of teachers and nurses who responded to online recruitment efforts and felt comfortable participating in a video-recorded online discussion. While participants provided valuable responses and a range of opinions that will guide oral health item development for our survey research, they clearly did not represent their many colleagues in schools across the region.

Findings from the focus group discussions with nurses and teachers nevertheless showed the critical importance of developing a strong relationship between the schools and community dental clinics, which parents rely on to provide their children's treatment. Locating reliable resources for proper access to care and finding dentists to care for the children were two of the main discussion topics during our sessions. An underutilized and less recognized resource for the healthcare delivery model is the dental school, which can offer students and residents as valuable partners in community care. A study demonstrated how a dental school-operated community clinic using dental students to provide care can be successfully implemented and meet the needs of the community, which highlighted how such a program can enhance the education and training for students and residents while meeting the needs of an underserved community [38,39]. A more recent model, Community-Based Clinical Education (CBCE), adopted by over a quarter of American dental schools, increased the access to care for local areas while enhancing the education and training for the students and residents utilizing a financially sustainable model $[39,40]$. Additionally, the early exposure of the dental students and residents to public service provided the opportunity for graduates to consider seeking employment in community public health systems $[40,41]$. 
Hence, establishing a collaboration between schools, community dental clinics and dental schools is critical to improving the overall health and well-being of children and the school community.

\section{Conclusions}

This study provides insights on the perceptions of child and adolescent oral health and practices of school-based professionals during the COVID-19 pandemic, which disrupted their contact with students and their parents. Employing remote technology, teachers and nurses assessed the advantages and challenges of this communication modality. All viewed the need for additional oral health training to be effective in their roles. Both teachers and nurses valued access to dental schools and community clinics as they set out to navigate their students' needs for dental care. The results suggest dimensions and questions important to item development for oral health surveys of children, adolescents, and parents to address screening, management, program assessment, and policy planning.

Author Contributions: Conceptualization, C.A.M., M.M., and H.L.; methodology, C.A.M., M.M., and D.X.; data curation, C.A.M., M.M., D.X., Y.H., and L.Z.; formal analysis, C.A.M., M.M., D.X., P.O., and E.A.; investigation, C.A.M., M.M., D.X., S. Y. L., J.S. and R.D.H.; resources, J.J.C. and H.L.; validation, J.S. and R.D.H.; writing - original draft preparation, C.A.M., M.M., D.X. and S.Y.L.; writing - review and editing, all authors; supervision, H.L.; project administration, H.L.; funding acquisition, H.L. All authors have read and agreed to the published version of the manuscript.

Funding: This research was funded by the National Institute of Dental and Craniofacial Research, grant number U01DE029491.

Institutional Review Board Statement: All subjects gave their informed consent for inclusion before they participated in the study. The study was conducted in accordance with the Declaration of Helsinki, and approved by the Institutional Review Board of the Office of Human Research Protection Program, University of California, Los Angeles (protocol code 20-000719 and date of approval 5/7/2020).

Informed Consent Statement: Informed consent was obtained from all subjects involved in the study.

Data Availability Statement: The data presented in this study are available on request from the corresponding author. The data are not publicly available due to research participants' privacy.

Acknowledgments: We would like to acknowledge the following individuals for their assistance in the recruitment process: Ms. Dale Gorman, Ms. Janis Lake, Ms. Stella Kim, Ms. Elizabeth Brummel, Ms. Valeria Salceda, and Ms. Cynthia Cervantes.

Conflicts of Interest: The authors declare no conflict of interest. The funders had no role in the design of the study; in the collection, analyses, or interpretation of data; in the writing of the manuscript, or in the decision to publish the results. 


\section{Appendix A}

\section{Standards for Reporting Qualitative Research (SRQR)}

Title and abstract

Title - Concise description of the nature and topic of the study Identifying the study as qualitative or indicating the approach (e.g., ethnography, grounded theory) or data collection methods (e.g., interview, focus group) is recommended

Abstract - Summary of key elements of the study using the abstract format of the intended publication; typically includes background, purpose, methods, results, and conclusions

\section{Introduction}

Problem formulation - Description and significance of the
problem/phenomenon studied; review of relevant theory and empirical work; problem statement

Purpose or research question - Purpose of the study and specific objectives or questions

\section{Methods}

Qualitative approach and research paradigm - Qualitative approach (e.g., ethnography, grounded theory, case study, phenomenology, narrative research) and guiding theory if appropriate; identifying the research paradigm (e.g., postpositivist, constructivist/ interpretivist) is also recommended;

Researcher characteristics and reflexivity - Researchers' characteristics that may influence the research, including personal attributes, qualifications/experience, relationship with participants, assumptions, and/or presuppositions; potential or actual interaction between researchers' characteristics and the research questions, approach, methods, results, and/or transferability

Context - Setting/site and salient contextual factors;

Sampling strategy - How and why research participants, documents, or events were selected; criteria for deciding when no further sampling was necessary (e.g., sampling saturation);

Ethical issues pertaining to human subjects - Documentation of approval by an appropriate ethics review board and participant consent, or explanation for lack thereof; other confidentiality and data security issues

Data collection methods - Types of data collected; details of data collection procedures including (as appropriate) start and stop dates of data collection and analysis, iterative process, triangulation of sources/methods, and modification of procedures in response to evolving study findings; 
Data collection instruments and technologies - Description of instruments (e.g., interview guides, questionnaires) and devices (e.g., audio recorders) used for data collection; if/how the instrument(s) changed over the course of the study

Units of study - Number and relevant characteristics of participants, documents, or events included in the study; level of participation (could be reported in results)

Data processing - Methods for processing data prior to and during analysis, including transcription, data entry, data management and security, verification of data integrity, data coding, and anonymization/deidentification of excerpts

Data analysis - Process by which inferences, themes, etc., were identified and developed, including the researchers involved in data analysis; usually references a specific paradigm or approach;

Techniques to enhance trustworthiness - Techniques to enhance trustworthiness and credibility of data analysis (e.g., member checking, audit trail, triangulation);

\section{Results/findings}

\begin{tabular}{|c|c|}
\hline $\begin{array}{l}\text { Synthesis and interpretation - Main findings (e.g., interpretations, } \\
\text { inferences, and themes); might include development of a theory or model, or } \\
\text { integration with prior research or theory }\end{array}$ & $5-10$ \\
\hline $\begin{array}{l}\text { Links to empirical data - Evidence (e.g., quotes, field notes, text excerpts, } \\
\text { photographs) to substantiate analytic findings }\end{array}$ & 6-10 \\
\hline
\end{tabular}

\section{Discussion}

Integration with prior work, implications, transferability, and contribution(s) to the field - Short summary of main findings; explanation of how findings and conclusions connect to, support, elaborate on, or challenge conclusions of earlier scholarship; discussion of scope of application/generalizability; identification of unique contribution(s) to scholarship in a discipline or field

Limitations - Trustworthiness and limitations of findings

\section{Other}

\begin{tabular}{|l|l|}
\hline $\begin{array}{l}\text { Conflicts of interest - Potential sources of influence or perceived influence } \\
\text { on study conduct and conclusions; how these were managed }\end{array}$ & 12 \\
\hline $\begin{array}{l}\text { Funding - Sources of funding and other support; role of funders in data } \\
\text { collection, interpretation, and reporting }\end{array}$ & 12 \\
\hline
\end{tabular}

\section{Appendix B}

Questions for Guiding Focus Group Discussions

Table B1. Questions for Teacher Sessions 


\begin{tabular}{|c|c|}
\hline Questions & Sub-Questions and Prompts \\
\hline $\begin{array}{l}\text { Question 1: What } \\
\text { kinds of children's } \\
\text { oral health problems } \\
\text { have you noticed? } \\
\text { How would you } \\
\text { characterize these } \\
\text { issues? }\end{array}$ & $\begin{array}{l}\text { 1. Emergencies such as painful teeth } \\
\text { 2. Other dental problems } \\
\text { 3. Not paying attention because of dental pain, like } \\
\text { pressing their hand against their cheek, etc. } \\
\text { 4. Having unsightly teeth } \\
\text { 5. Bad breath } \\
\text { 6. Students missing school because of dental problems } \\
\text { 7. Problems accessing dental care } \\
\text { 8. Helping students address oral health problems } \\
\text { 9. Addressing oral health problems with parents } \\
\text { 10. The role of the administration in oral health } \\
\text { 11. Finding dental providers who will accept your stu- } \\
\text { dents as patients. } \\
\text { 12. Dental programs at school that interfere with your } \\
\text { teaching responsibilities }\end{array}$ \\
\hline $\begin{array}{l}\text { Question 2: When } \\
\text { you suspect that a } \\
\text { child has an oral } \\
\text { health problem, how } \\
\text { do you feel about } \\
\text { discussing this } \\
\text { problem with the } \\
\text { child and or the } \\
\text { parent? }\end{array}$ & \\
\hline $\begin{array}{l}\text { Question 3: Would } \\
\text { you describe some } \\
\text { instances where you } \\
\text { engaged in such } \\
\text { discussions? }\end{array}$ & $\begin{array}{l}\text { 1. Would you describe any interactions you have had } \\
\text { working with school nurses on oral health issues re- } \\
\text { garding parents or children? }\end{array}$ \\
\hline $\begin{array}{l}\text { Question 4: After } \\
\text { we complete these } \\
\text { focus groups, we } \\
\text { will be conducting } \\
\text { focus groups with } \\
\text { students and also } \\
\text { their parents. I } \\
\text { would like to ask } \\
\text { your advice on how } \\
\text { to engage parents } \\
\text { and their children in } \\
\text { participating in } \\
\text { focus groups and }\end{array}$ & $\begin{array}{l}\text { 1. How can teachers help in recruiting parents to partici- } \\
\text { pate in focus groups and surveys? How about stu- } \\
\text { dents? } \\
\text { 2. To what extent should teachers be involved in distrib- } \\
\text { uting information regarding our study? } \\
\text { 3. Should we use posters and handouts at the school? } \\
\text { 4. Would you agree to send home invitations with your } \\
\text { students to have them and one of their parents partici- } \\
\text { pate in this project? } \\
\text { 5. Is the teacher important to recruit parents and stu- } \\
\text { dents that are underserved and disadvantaged? Do } \\
\text { you have any suggestions? }\end{array}$ \\
\hline
\end{tabular}




\begin{tabular}{|c|c|}
\hline $\begin{array}{l}\text { the surveys that we } \\
\text { will be developing. }\end{array}$ & $\begin{array}{l}\text { 6. What about, community organizations, churches, etc. } \\
\text { that could help us recruit these families? } \\
\text { 7. We do not want to recruit from dental clinics or prac- } \\
\text { tices, since they already are treating these students. } \\
\text { 8. What about incentives for the students and their par- } \\
\text { ents? }\end{array}$ \\
\hline $\begin{array}{l}\text { Question 5: Since } \\
\text { we are using this } \\
\text { remote technology } \\
\text { to conduct these } \\
\text { focus groups, we } \\
\text { would like your } \\
\text { opinions on how } \\
\text { you felt about this } \\
\text { group and if there is } \\
\text { anything we can do } \\
\text { to make it work } \\
\text { better? }\end{array}$ & $\begin{array}{l}\text { 1. If you have been teaching using Zoom-like technolo- } \\
\text { gies, what has been your experience? } \\
\text { 2. How did your participation in this Zoom focus group } \\
\text { differ from that of in-person focus groups or meet- } \\
\text { ings? How? } \\
\text { 3. How did you feel about your ability to relate to the } \\
\text { other participants in the group and the group leaders? } \\
\text { 4. What about your comfort level in participation with } \\
\text { other members of the group? } \\
\text { 5. Are there any things that you liked about the virtual } \\
\text { focus group? } \\
\text { 6. How about things that you disliked or annoyed you } \\
\text { about the virtual focus group? }\end{array}$ \\
\hline
\end{tabular}

Table B2. Questions for Nurse Sessions

\begin{tabular}{|c|c|}
\hline Questions & Sub-Questions and Prompts \\
\hline $\begin{array}{l}\text { Question 1: What } \\
\text { types of oral health } \\
\text { problems do you } \\
\text { deal with in a } \\
\text { typical week? }\end{array}$ & $\begin{array}{l}\text { 1. Painful Tooth } \\
\text { 2. Swelling in the face related to dental decay } \\
\text { 3. Trauma to the face, e.g., broken tooth caused by a fall } \\
\text { 4. Several front teeth exhibiting decay } \\
\text { 5. Students ashamed of the appearance of his/her teeth } \\
\text { 6. After dental screening students who have active den- } \\
\text { 7. Informing parents that their child needs to have den- } \\
\text { tal treatment }\end{array}$ \\
\hline $\begin{array}{l}\text { Question 2: When a } \\
\text { child presents with } \\
\text { one of these oral } \\
\text { health problems, } \\
\text { how do you address } \\
\text { them? }\end{array}$ & $\begin{array}{l}\text { 1. Provide pain medication. } \\
\text { 2. Refer to a dentist } \\
\text { a. To a school-based clinic } \\
\text { b. To a community clinic } \\
\text { 3. Place an ice pack } \\
\text { 4. Call the parent } \\
\text { 5. Send student back to class }\end{array}$ \\
\hline $\begin{array}{l}\text { Question 3: How do } \\
\text { children in need get } \\
\text { to you for oral } \\
\text { health services? }\end{array}$ & $\begin{array}{l}\text { 1. They come on their own } \\
\text { 2. Their teacher sends them } \\
\text { 3. Their parents send them } \\
\text { 4. Routinely assigned }\end{array}$ \\
\hline
\end{tabular}




\begin{tabular}{|c|c|}
\hline $\begin{array}{l}\text { Question 4: Beyond } \\
\text { dealing with } \\
\text { individual students, } \\
\text { how would you } \\
\text { describe the other } \\
\text { types of oral health- } \\
\text { related activities you } \\
\text { engage in.? }\end{array}$ & $\begin{array}{l}\text { 1. Teaching good oral health behaviors: oral hygiene, } \\
\text { good dietary practices, understanding dental disease } \\
\text { 3. Arranging for dental screenings } \\
\text { 4. Counseling students and parents regarding oral } \\
\text { health and dental treatment } \\
\text { 6. Wrranging dental care for students in need } \\
\text { 7. Where do you usually refer students: practice practi- } \\
\text { sues and community dental clinics, other venues? } \\
\text { 8. Describe your relationship with teachers regarding } \\
\text { the oral health of the students }\end{array}$ \\
\hline $\begin{array}{l}\text { Question 5: } \\
\text { Describe the issues } \\
\text { associated with } \\
\text { access to dental care } \\
\text { for the students. } \\
\text { Provide examples } \\
\text { that illustrate the } \\
\text { problem. }\end{array}$ & $\begin{array}{l}\text { 1. Few dental care providers available to your popula- } \\
\text { tion } \\
\text { 2. Dentists not accepting Medi-Cal } \\
\text { 3. Recent immigrants not willing to sign-up for dental } \\
\text { care programs } \\
\text { 4. Lack of transportation } \\
\text { 5. Lack of treatment for special care patients } \\
\text { 6. Lack of access to specialty services } \\
\text { 7. Lack of access to emergency care } \\
\text { 8. Not enough time for oral health teaching programs } \\
\text { 9. Lack of resources, e.g., toothbrushes, teaching aids, etc } \\
\text { 10. Problem engaging teachers to be concerned about oral } \\
\text { 11. Problems dealing with parents } \\
\text { 12. Dealing with the administration }\end{array}$ \\
\hline $\begin{array}{l}\text { Question 6: After } \\
\text { we complete these } \\
\text { focus groups, we } \\
\text { will be conducting } \\
\text { focus groups with } \\
\text { students and also } \\
\text { their parents. I } \\
\text { would like to ask } \\
\text { your advice on how } \\
\text { to engage parents } \\
\text { and their children in } \\
\text { participating in } \\
\text { focus groups and } \\
\text { the surveys that we } \\
\text { will be developing. }\end{array}$ & $\begin{array}{l}\text { 1. How can nurses help in recruiting parents to partici- } \\
\text { pate in focus groups and surveys? How about stu- } \\
\text { dents? } \\
\text { 2. To what extent should nurses be involved in distrib- } \\
\text { uting information regarding our study? } \\
\text { 3. Should we use posters and handouts at the school? } \\
\text { 4. Would you agree to send home invitations with your } \\
\text { students to have them and one of their parents partici- } \\
\text { pate in this project? } \\
\text { 5. Is the nurse important to recruiting parents and stu- } \\
\text { dents that are underserved and disadvantaged? Do } \\
\text { you have any suggestions? } \\
\text { 6. What about, community organizations, churches, etc. } \\
\text { that could help us recruit these families? }\end{array}$ \\
\hline
\end{tabular}


7. We do not want to recruit from dental clinics or practices, since they already are treating these students.

8. What about incentives for the students and their parents?

Question 7: Since we are using this remote technology to conduct these focus groups with parents and also with students, we would like your opinions on how you felt about it and if there is anything we can do to make it work better?
1. If you have been parents using Zoom-like technologies, what has been your experience?

2. How did your participation in this Zoom focus group differ from that of in-person focus groups or meetings? How?

3. How did you feel about your ability to relate to the other participants in the group and to the group leaders?

4. What about your comfort level in participation with other members of the group?

5. Are there any things that you liked about the virtual focus group?

6. How about things that you dislike or annoyed you about the virtual focus group?

\section{References}

1. National Institutes of Health Oral Health in America: Advances and Challenges; Bethesda, MD, 2021;

2. Ní Ríordáin, R.; Wiriyakijja, P. Patient Reported Outcome and Experience Measures of Oral Disease in Oral Medicine. British Dental Journal 2017, 223, 713-718, doi:10.1038/SJ.BDJ.2017.889.

3. Ader, D.N. Developing the Patient-Reported Outcomes Measurement Information System (PROMIS). Medical Care 2007, 45, doi:10.1097/01.MLR.0000260537.45076.74.

4. $\quad$ Reeve, B.B.; Hays, R.D.; Bjorner, J.B.; Cook, K.F.; Crane, P.K.; Teresi, J.A.; Thissen, D.; Revicki, D.A.; Weiss, D.J.; Hambleton, R.K.; et al. Psychometric Evaluation and Calibration of Health-Related Quality of Life Item Banks: Plans for the Patient-Reported Outcomes Measurement Information System (PROMIS). Medical Care 2007, 45, doi:10.1097/01.MLR.0000250483.85507.04.

5. Arora, A.; Bedros, D.; Bhole, S.; Eastwood, J.; Moody, G. A Qualitative Evaluation of the Views of Child and Family Health Nurses on the Early Childhood Oral Health Education Materials in New South Wales, Australia. Health Promotion Journal of Australia 2012, 23, 112-116, doi:10.1071/HE12112.

6. Bradbury-Jones, C.; Innes, N.; Evans, D.; Ballantyne, F.; Taylor, J. Dental Neglect as a Marker of Broader Neglect: A Qualitative Investigation of Public Health Nurses' Assessments of Oral Health in Preschool Children. BMC Public Health 2013, 13, 1-12, doi:10.1186/1471-2458-13-370/TABLES/2.

7. Walker, D.; Myrick, F. Grounded Theory: An Exploration of Process and Procedure. Qualitative Health Research 2006, 16, 547-559, doi:10.1177/1049732305285972.

8. Petersen, P.E.; Peng, B.; Tai, B.; Bian, Z.; Fan, M. Effect of a School-Based Oral Health Education Programme in Wuhan City, Peoples Republic of China. International Dental Journal 2004, 54, 33-41, doi:10.1111/j.1875-595x.2004.tb00250.x.

9. Barros, V. de A.; Costa, S.M.; Zanin, L.; Flório, F.M. Evaluation of an Educational Activity in the Oral Health of Students. International Journal of Dental Hygiene 2017, 15, 23-29, doi:10.1111/IDH.12152.

10. de Farias, I.A.; de Araújo Souza, G.C.; Ferreira, M.Â.F. A Health Education Program for Brazilian Public Schoolchildren: The Effects on Dental Health Practice and Oral Health Awareness. Journal of Public Health Dentistry 2009, 69, 225-230, doi:10.1111/J.1752-7325.2009.00127.X.

11. Liu, M.; Zhu, L.; Zhang, B.X.; Petersen, P.E. Changing Use and Knowledge of Fluoride Toothpaste by Schoolchildren, Parents and Schoolteachers in Beijing, China. International Dental Journal 2007, 57, 187-194, doi:10.1111/J.1875595X.2007.TB00124.X.

12. Abuhaloob, L.; Petersen, P.E. Oral Health Status and Oral Health Behaviour among 5- to 6-Year-Old Palestinian Schoolchildren - Towards Engagement of Parents and Schoolteachers for Oral Health through Schools. Oral Health E Preventive Dentistry 2021, 19, 673-682, doi:10.3290/J.OHPD.B2448571.

13. Liu, H.Y.; Chen, J.R.; Hsiao, S.Y.; Huang, S. te Caregivers' Oral Health Knowledge, Attitude and Behavior toward Their Children with Disabilities. Journal of Dental Sciences 2017, 12, 388, doi:10.1016/J.JDS.2017.05.003. 
14. Nashine, N.; Bansal, A.; Tyagi, P.; Jain, M.; Jain, A.; Tiwari, U. Comparison and Evaluation of Attitude and Knowledge Towards the Management of Dental Injury in School Teachers Before and After Oral Health Education. International Journal of Clinical Pediatric Dentistry 2018, 11, 425, doi:10.5005/JP-JOURNALS-10005-1551.

15. Yılmaz, G.; Riad, A.; Krsek, M.; Kurt, H.; Attia, S. Oral Health-Related Knowledge, Attitudes and Behaviours of Elementary School Teachers. International Journal of Environmental Research and Public Health 2021, 18, doi:10.3390/IJERPH18116028.

16. PC, M.; V, S.; N, M.; TD, V.; MC, D. Knowledge, Attitudes, and Practices of School Teachers toward Oral Health in Davangere, India. International Journal of Clinical Pediatric Dentistry 2017, 10, 89-95, doi:10.5005/JP-JOURNALS-100051413.

17. Garry, B.; Boran, S. Promotion of Oral Health by Community Nurses. British Journal of Community Nursing 2017, 22, 496502, doi:10.12968/BJCN.2017.22.10.496.

18. Gustafsson, A.; Skogsberg, J.; Rejnö, A. Oral Health Plays Second Fiddle in Palliative Care: An Interview Study with Registered Nurses in Home Healthcare. BMC Palliative Care 2021, 20, 1-11, doi:10.1186/S12904-021-00859-3/TABLES/2.

19. Hedman, E.; Ringberg, K.; Gabre, P. Oral Health Education for Schoolchildren: A Qualitative Study of Dental Care Professionals' View of Knowledge and Learning. International Journal of Dental Hygiene 2009, 7, 204-211, doi:10.1111/J.1601-5037.2009.00391.X.

20. Luo, W.; Lee, G.H.M.; Nalabothu, P.; Kumar, H. Paediatric Dental Care during and Post-COVID-19 Era: Changes and Challenges Ahead. Pediatric Dental Journal 2021, 31, 33-42, doi:10.1016/J.PDJ.2021.01.003.

21. Yang, F.; Yu, L.; Qin, D.; Hua, F.; Song, G. Online Consultation and Emergency Management in Paediatric Dentistry during the COVID-19 Epidemic in Wuhan: A Retrospective Study. International Journal of Paediatric Dentistry 2021, 31, 5-11, doi:10.1111/IPD.12722.

22. Schulz-Weidner, N.; Schlenz, M.A.; Krämer, N.; Boukhobza, S.; Bekes, K. Impact and Perspectives of Pediatric Dental Care during the COVID-19 Pandemic Regarding Unvaccinated Children: A Cross-Sectional Survey. International Journal of Environmental Research and Public Health 2021, 18, doi:10.3390/IJERPH182212117.

23. Patel, N.; Viswanathan, A.; Lee, J.; Barrow, S.; Cant, A.; Sanghvi, R.; Deseta, M.; Layton, J.; Bhujel, N.; Sheehy, E.C. Paediatric Dental A\&E Service during the COVID-19 Pandemic in the Greater London Area. European Archives of Paediatric Dentistry 2021, 22, 507-513, doi:10.1007/S40368-020-00589-9.

24. Halliday, M.; Mill, D.; Johnson, J.; Lee, K. Let's Talk Virtual! Online Focus Group Facilitation for the Modern Researcher. Research in Social and Administrative Pharmacy 2021, 17, 2145-2150, doi:10.1016/J.SAPHARM.2021.02.003.

25. Woodyatt, C.R.; Finneran, C.A.; Stephenson, R. In-Person Versus Online Focus Group Discussions: A Comparative Analysis of Data Quality. Qualitative Health Research 2016, 26, 741-749, doi:10.1177/1049732316631510.

26. Reisner, S.L.; Randazzo, R.K.; White Hughto, J.M.; Peitzmeier, S.; DuBois, L.Z.; Pardee, D.J.; Marrow, E.; McLean, S.; Potter, J. Sensitive Health Topics With Underserved Patient Populations: Methodological Considerations for Online Focus Group Discussions. Qualitative Health Research 2018, 28, 1658-1673, doi:10.1177/1049732317705355.

27. Aligato, M.F.; Endoma, V.; Wachinger, J.; Landicho-Guevarra, J.; Bravo, T.A.; Guevarra, J.R.; Landicho, J.; McMahon, S.A.; Reñosa, M.D.C. “Unfocused Groups”: Lessons Learnt amid Remote Focus Groups in the Philippines. Family Medicine and Community Health 2021, 9, doi:10.1136/FMCH-2021-001098.

28. Service Planning Areas (SPAs) for Los Angeles County, California Available online: https://www.laalmanac.com/health/he798.php (accessed on 12 January 2022).

29. Marcus, M.; Maida, C.A.; Wang, Y.; Xiong, D.; Hays, R.D.; Coulter, I.D.; Lee, S.Y.; Spolsky, V.W.; Shen, J.; Crall, J.J.; et al. Child and Parent Demographic Characteristics and Oral Health Perceptions Associated with Clinically Measured Oral Health. JDR Clinical and Translational Research 2018, 3, doi:10.1177/2380084418774549.

30. Liu, H.; Hays, R.; Wang, Y.; Marcus, M.; Maida, C.; Shen, J.; Xiong, D.; Lee, S.; Spolsky, V.; Coulter, I.; et al. Short Form Development for Oral Health Patient-Reported Outcome Evaluation in Children and Adolescents. Qual Life Res 2018, 27, 1599-1611, doi:10.1007/s11136-018-1820-9.

31. Maida, C.A.; Marcus, M.; Hays, R.D.; Coulter, I.D.; Ramos-Gomez, F.; Lee, S.Y.; McClory, P.S.; Van, L. v.; Wang, Y.; Shen, J.; et al. Qualitative Methods in the Development of a Parent Survey of Children's Oral Health Status. Journal of Patient-Reported Outcomes 2018, 2, 1-18, doi:10.1186/s41687-018-0033-x.

32. O'Brien, B.C.; Harris, I.B.; Beckman, T.J.; Reed, D.A.; Cook, D.A. Standards for Reporting Qualitative Research: A Synthesis of Recommendations. Academic Medicine 2014, 89, 1245-1251, doi:10.1097/ACM.0000000000000388.

33. Gray, L.M.; Wong-Wylie, G.; Rempel, G.R.; Cook, K. Expanding Qualitative Research Interviewing Strategies: Zoom Video Communications. The Qualitative Report 2020, 25, 1292-1301.

34. Qualitative Data Analysis Software I NVivo Available online: https://www.qsrinternational.com/nvivo-qualitativedata-analysis-software/home (accessed on 13 January 2022).

35. MedCalc's Comparison of Two Rates Available online: https://www.medcalc.org/calc/rate_comparison.php (accessed on 1 February 2022).

36. Dudovitz, R.N.; Valiente, J.E.; Espinosa, G.; Yepes, C.; Padilla, C.; Puffer, M.; Slavkin, H.C.; Chung, P.J. A School-Based Public Health Model to Reduce Oral Health Disparities. Journal of Public Health Dentistry 2018, 78, 9-16, doi:10.1111/JPHD.12216. 
37. Buerlein, J. Promoting Children's Oral Health. A Role for School Nurses in Prevention, Education, and Coordination. NASN School Nurse 2010, 25, 26-29, doi:10.1177/1942602X09353053.

38. Christie, D.; Maida, C.A.; Freed, J.R.; Marcus, M. Identifying and Responding to Competing Needs: A Case Study of a Dental School-Operated Community Dental Clinic. Journal of Dental Education 2003, 67, 1243-1251, doi:10.1002/J.00220337.2003.67.11.TB03716.X.

39. Lee, C.; Li, D.; Ramaswamy, V.; Fitzgerald, M.; Hamerink, H.; Piskorowski, W.A. One School's Solution to Oral Health Care Access. Journal of the Michigan Dental Association 2017, 99, 54-58.

40. Formicola, A.J.; Bailit, H.L. Community-Based Dental Education: History, Current Status, and Future. Journal of Dental Education 2012, 76, 98-106, doi:10.1002/J.0022-0337.2012.76.1.TB05238.X.

41. Piskorowski, W.A.; Stefanac, S.J.; Fitzgerald, M.; Green, T.G.; Krell, R.E. Influence of Community-Based Dental Education on Dental Students' Preparation and Intent to Treat Underserved Populations. Journal of Dental Education 2012, 76, 534-539, doi:10.1002/J.0022-0337.2012.76.5.TB05286.X. 